\title{
Post-2008 Brazilian fiscal policy: an interpretation through the analysis of fiscal multipliers
}

\author{
Celso José Costa Junior \\ Professor - Universidade Estadual de Ponta Grossa (UEPG) \\ Endereço: Praça Santos Andrade, no 1 - Centro - Ponta Grossa - Paraná \\ CEP: 84010790 - E-mail: cjcostaj@yahoo.com.br
}

\author{
Alejandro C. García Cintado \\ Professor - Pablo de Olavide University \\ Department of Economics, Quantitative Methods and Economic History \\ Endereço: Ctra. Utrera, km.1 - Building 3, floor 3, office no 3.3.16 - 41013 Seville (SPAIN). \\ E-mail: agcintado@upo.es
}

\author{
Armando Vaz Sampaio \\ Professor - Universidade Federal do Paraná (UFPR) \\ Endereço: Av. Lothário Meissner, 3400 Jd. Botânico - Curitiba - Paraná \\ CEP: 80210170 - E-mail: avsampaio@ufpr.br
}

Recebido: 28/07/2015. Aceite 23/11/2016.

\begin{abstract}
The global crisis that erupted in 2007 led many countries to embark on countercyclical fiscal policies as a way to cushion the blow of a depressed aggregate demand. Advocates of discretionary measures emphasize that fiscal policy can indeed stimulate the economy. The main goal of this work is to assess whether the fiscal policies pursued by the Brazilian government in the aftermath of the 2008 crisis, succeeded in bringing the economy back on track in a sustainable fashion. To this end, the fiscal multipliers of five different shocks are studied in a small open-economy New Keynesian framework. Our results point to the government spending and public investment as the most effective fiscal tools for combating the crisis. However, the highest fiscal multiplier turned out to be the one associated with excise tax reductions.
\end{abstract}

\section{Keywords}

DSGE Models. Fiscal Multipliers. New Keynesian Model.

\section{Resumo}

A crise global que surgiu in 2007 levou a muitos países a embarcarem em políticas fiscais anticíclicas como forma de amortecer o impacto de uma demanda agregada em queda. Os defensores de medidas discricionárias enfatizam que a política fiscal pode de fato estimular a economia. O principal objetivo deste trabalho é avaliar se as políticas fiscais desenvolvidas pelo governo brasileiro na sequência da crise de 2008 tiveram sucesso em por a economia no caminho da recuperação de uma maneira sustentável.

\footnotetext{
The first author thanks CAPES for financial support through the PNPD grant. The authors are grateful to the anonymous reviewer, the participants of the EcoMod 2016 International Conference on Economic Modeling, 2016, Lisbon and the participants of the 19th International Conference on Macroeconomic Analysis and International Finance, 2015, Crete.
} 
Para fazer isso, estudam-se os multiplicadores fiscais de cinco choques diferentes através de um modelo Novo-Keynesiano de uma pequena economia aberta. Nossos resultados apontam para o gasto público e o investimento público como os instrumentos fiscais mais efetivos no combate à crise. Porém, o multiplicador fiscal mais alto resultou ser o associado às reduções no imposto sobre o consumo.

\section{Palavras-Chave}

Modelos DSGE. Multiplicadores Fiscais. Novo Modelo Keynesiano.

\section{JEL Classification}

C63. E37. E62.

\section{Introduction}

In 2008 the Brazilian government, in attempt to unleash more resources to households so as to increase private consumption, widened the existing range of top marginal rates in which the personal income tax was structured. In addition, it lowered the tax on manufactured products (IPI) in the acquisition of cars and trucks. On the spending side, public investment plans as well as government current expenditure growth were maintained throughout the year 2009 in the midst of falling fiscal revenues owing to the economic slowdown (MOREIRA, 2010).

Also, with the aim of boosting aggregate demand, the Brazilian government launched the so-called PAC 2 in March 2010, with an estimate of around $\mathrm{R} \$ 1,59$ trillions. This program, which was an extension of the Growth Acceleration Program (Programa de Aceleração do Crescimento - PAC-, ${ }^{1}$ in Portuguese) created in January 2007, projected investments of $\mathrm{R} \$ 503,9$ billions up until 2010.

This article aims to shed some light on the discussion about the effects of the post-2008 Brazilian fiscal policy, on both the revenue and the expenditure sides. Specifically, we set out to examine whether this fiscal expansion had a positive (and permanent) effect on the economic activity by focusing on the analysis of the fiscal multiplier on each sort of stimulus considered, namely tax cuts on

1 PAC is a Brazilian federal government's program consisting of a set of economic policies (investment in infrastructure, housing, transport, energy and water, among others) targeted at contributing to the acceleration of Brazilian economic growth. 
consumption, on labor income, on capital gains, government consumption and investment shocks. The baseline model we employ is a small open-economy New Keynesian one with the standard frictions (price and wage rigidity, habit formation in consumption, investment adjustment costs, Ricardian and non-Ricardian consumers, cost of servicing a growing net foreign debt and variable capital utilization) in which both public spending and tax shocks are included and the parameters have been estimated through Bayesian methodology. It also features public capital stock as an input, which allows for the analysis of the effects of shocks to public investment on the marginal productivity of private inputs and on the GDP.

The analyses carried out in this paper highlight that output was mainly driven by changes in the two expenditure-based measures considered, current spending and public investment. From 2003 through 2006, cuts in both expenditure items were instrumental in decreasing aggregate demand. Furthermore, subsequent increases in both items, due to the implementation of PACl and, particularly PAC2, were found to be the primary forces behind the renewed impetus to the economic activity and thus, the main lever to overcome the crisis. However, the effects of these expansionary measures only lasted until 2013, when the economy started to deteriorate. Besides, we also find that for the case of Brazil, the fiscal multipliers studied are remarkably low and seem to be in line with the figures that the literature sets for high-debt emerging and developing countries (Batini et al., 2014; Ilzetzki et al., 2013). As far as the size of the fiscal multiplier is concerned, the most effective stimulus was the consumption-tax cut, followed by the rise in current spending. Income-tax related measures and increases in public investment appear to have negligible effects on output. According to our results, the Brazilian government would then be advised to lean on consumption-tax cuts and increases in current expenditure as a way to attain the highest efficacy at boosting output.

The remainder of the paper is organized as follows: section 2 introduces the definition and Literature; section 3 shows the model; sections 4 and 5 explain the data, calibration and estimation of the structural parameters, respectively. Section 6 presents the results; after, section 7 concludes. 


\section{Fiscal multiplier: definition and literature}

This section intends to lay out the fiscal multiplier definition used throughout this paper, as well as present the national and international literature covering the topic at hand.

Definition 2.1 (Fiscal multiplier). It is the ratio of a change in output $(\Delta Y)$ to an exogenous change in fiscal policy (increase in public spending, $(\Delta G)$, or tax cut, $(\Delta T)$ ). There are different sorts of multipliers:

Impact multiplier $=\frac{\Delta Y_{t}}{\Delta G_{t}}$

Multiplier at horizon $\mathrm{N}=\frac{\Delta Y_{t+N}}{\Delta G_{t}}$

Cumulative multiplier $=\frac{\sum_{j=0}^{N} \Delta Y_{t+j}}{\sum_{j=0}^{N} \Delta G_{t+j}}$

In discussing the values of the multipliers associated with each fiscal policy measure, we choose to work with the latter as it is the most common one used within the literature.

Due to the rapid development of the fiscal policy literature, it is now well accepted that the size of the fiscal multipliers is influenced by several factors. Every time the government carries out an expansionary fiscal policy, a bit of that effect is saved and/or used to buy imports (this is referred to as leakages in the literature). These leakages are greater when it comes to tax exemptions than in the case of public spending, as the latter impacts the aggregate demand directly. That said, some relevant variables that account for the size of those leakages are the marginal propensity to consume, the marginal propensity to import, liquidity-constrained agents (non-Ricardian households) and the existence of automatic stabilizers, among others. The way the monetary authority reacts to the fiscal shock is also decisive, as if it accommodates the ensuing demand expansion by holding the basic interest rate constant in response to this higher aggregate demand -, investment and consumption will fall less than 
in the case the central bank pursues a tighter monetary policy (lower crowding-out effect).

Finally, it can be interesting to present the expected values for the fiscal multipliers. A "rule of thumb" is a public-spending multiplier $\left(\frac{\Delta Y}{\Delta G}\right)$ between 1 and 1,5 for the large economies, between 0,5 and 1 for medium-size economies, and smaller than 0,5 in case of small economies (the Brazilian case). Overall, multipliers associated with tax revenues, public investment or income transfers amount to half of the value of the spending multipliers. Having negative fiscal multipliers is possible, especially if the fiscal boost worsens the public debt sustainability (Spilimbergo et al., 2009).

The national literature is relatively scant, and this scarcity grows when it comes to articles employing DSGE models to address this issue. However, three articles can be deemed as the pioneers in closing this gap. The first one is Moura (2015), where the author uses a DSGE model to derive present-value multipliers related to public consumption and investment. Although the aforementioned model has significant strengths, its main weakness has to do with the fact that the author does not consider distortionary taxes into the model, which does not contribute to enriching the debate. His results show that, in spite of the effect of public consumption on GDP being positive on impact, the long-run effect is smaller than unity in all the scenarios analyzed (for some parameterizations the said effect was even negative). According to the author, the cause of this low long -run value resides in the need of fiscal adjustment, leading to future decreases in public consumption and investment. On the contrary, not only does the government investment have a positive impact on the economy in the short run, but its long-run effect exceeds the unity. This is because the bigger stock of public capital brings about productivity gains for the whole economy.

The second paper is Cavalcanti and Vereda (2014) in which they quantify and compare the macroeconomic impacts of several kinds of public spending - purchases of goods and services, investments, social transfers and public wages and salaries - under different fiscal rules. This work is however limited in the sense that the analysis relies on a calibrated but not estimated DSGE model for the Brazilian economy. The chief results obtained by those authors indicate that, 
under rules of tax-based fiscal consolidations, the larger positive short-run effect on GDP arises from the increase in public employment, whereas the most negative effect associates itself with income transfers. On the other hand, under fiscal rules for some spending item, there does not exist any type of public outlay that gives rise to a significant positive impact on GDP in the short run. In the medium run, the best way to make GDP grow is via increases in public investment, which can lead to substantially greater-than-unity multipliers, depending on the fiscal rule in use. In addition, under a permanent balanced budget policy, the majority of public expenditure items yield negligible or even negative multipliers, as opposed to positive ones when a policy of delayed or partial fiscal adjustment is conducted.

Carvalho and Valli (2011) created a model with great acceptance among academics working with DSGE in Brazil. These authors introduced that governments intervene in the economy through the accumulation of public capital with an impact on factor productivity and in the overall demand for investment goods. Different from this work, where the firm does not choose the amount of public capital that one will use in its production process, Carvalho and Valli (2011) assumed that firms can selectively choose between public and private capital services. This modeling choice was intended to capture the significant presence of the Brazilian government in the productive sector of the economy. This model works with two types of households; the first has more specialized labor services ${ }^{2}$ where the second does not. Wages and prices have rigidities but there are still consumption habits. Among the shocks proposed by the authors, there are shocks in the primary surplus/GDP, in the public investments and in public transfers/GDP.

In the international literature, DSGE models are relied upon even more intensely in the study of fiscal multipliers. Zubairy (2010) estimates a DSGE model with fiscal features using Bayesian techniques for the U.S. economy. The author finds a public-spending multiplier of 1,12 , in contrast to the tax exemptions from labor income and capital income, whose multipliers are 0,13 and 0,33 , respectively. Christiano et al. (2009), by means of a DSGE model, seek to obtain a greater-than-one multiplier when the economy is at the zero lower bound. They come up with a multiplier effect which is subs-

2 Just a different way of denominating non-Ricardian agents.

Estud. Econ., São Paulo, vol.47, n.1, p.93-124 , jan.-mar. 2017 
tantially larger than one, this result being fully consistent with the behavior of the main macroeconomic variables over the 2008 crisis. Woodford (2010) also tackles shocks to government expenditures. Throughout this article, the author aims at providing an explanation for the main factors determining the efficiency of fiscal stimulus on output and employment by using a New-Keynesian model. Results show that delays in the price and wage adjustment can raise the size of public-spending multipliers, and that its value would be bigger than one as long as the monetary authority keeps interest rates unchanged. Meanwhile, that value can be far lower if the monetary authority bids up interest rates in response to a rise in spending.

It may also be worth reviewing some articles that do not resort to DSGE models in accounting for the effectiveness of fiscal policies and their associated multipliers for the case of Brazil. Cavalcanti and Silva (2010) attempt to understand the effects of fiscal policy for this economy over a period spanning 1995 to 2008 by making use of a VAR model that emphasizes the role of public debt in the efficiency of fiscal policy. Their results suggest that there exists an explicit role of public debt in the evolution of the fiscal variables over economic activity. Therefore, a fiscal shock influencing public debt should engender future movements in public expenditures and revenues which tend to attenuate the initial effects of the shock.

Mendonça et al. (2010) deploy data spanning from 1995 to 2007, so as to investigate the effects of fiscal shocks on the Brazilian economy. Their results imply that private consumption and interest rates rise as government spending unexpectedly goes up. Nevertheless, output is very likely to fall. These results point to the presence of crowding-out effects between public spending and private investment. As regards the expansionary shock to revenues, it is possible for output to drop in the short run, but a positive reaction of this variable is likely to materialize in the longer run.

Peres and Ellery Junior (2009) examine the dynamic effects of shocks to federal fiscal variables on the economic activity in Brazil for the post-Real-Plan period by utilizing a Structural VAR comprising output, public spending and net taxes. These authors compare their results with those found in the international literature for the case of the American economy and other OCDE countries and come 
to the conclusion that they are similar in that the output response to fiscal shocks is positive but small in both economic areas.

Fantinatti (2015) looks into the policy of tax exemption applied to the IPI on durable goods during the post-crisis 2008 period. His results underline the fact that fiscal boosts in the sector of durable goods were unimportant, and apparently the best tax-exemption policy would be to foster the sector of non-durable goods on account of two main reasons: the share of non-durable goods over GDP; and the assumption that government consumption is biased towards non-durable goods, which renders fiscal adjustment less imperative.

\section{The model}

Our model follows the New-Keynesian tradition and, in addition to price frictions, it features wage rigidity. It also encompasses non-Ricardian agents, habit formation in consumption, investment adjustment cost, cost of servicing a growing net foreign debt, and variable capital utilization. This section intends to describe the economy under discussion by focusing first on households, then presenting firms, next the government and ending with the external sector.

\subsection{Households}

There is a continuum of households indexed by $j \in[0,1]$. A share $\omega_{R}$ of this continuum of households indexed by $R \in\left[0, \omega_{R}\right)$ have access to financial markets, and they behave as Ricardian agents, that is, they maximize their intertemporal utility. The remaining share of households indexed by $N R \in\left(\omega_{R}, 1\right]$ cannot save and simply consume their after-tax disposable income. This type of agent is referred to as non-Ricardian household in the literature.

\subsubsection{Determining consumption and saving of the Ricardian household}

The representative ricardian household is assumed to maximize its inter-temporal utility by choosing consumption, savings, investment and leisure. As for the saving decision, she can choose between 
three different instruments - physical capital, foreign bonds and government bonds, indexed by $\mathrm{j}$. In other words, this agent elects how much to consume, how much to work and how much to save and invest by accumulating financial assets and physical capital in order to maximize the discounted stream of expected utility.

The stand-in consumer's formal problem boils down to,

$$
\max _{C_{R, j, t}, K_{j, t+1}^{P}, U_{j, t}, I_{j, t+1}^{P}, B_{j, t+1}, B_{j, t+1}^{F}} E_{t} \sum_{t=0}^{\infty} \beta^{t} S_{t}^{P}\left[\frac{\left(C_{R, j, t}-\phi_{C} C_{R, j, t-1}\right)^{1-\sigma}}{1-\sigma}-S_{t}^{L} \frac{L_{R, j, t}^{1+\varphi}}{1+\varphi}\right]
$$

subject to her budget constraint,

$$
\begin{aligned}
P_{t}\left(1+\tau_{t}^{C}\right)\left(C_{R, j, t}+I_{j, t}^{P}\right)+\frac{B_{j, t+1}}{R_{t}^{B}}+R_{t-1}^{F} S_{t} B_{j, t}^{F}=W_{t} L_{R, j, t}\left(1-\tau_{t}^{L}\right)+R_{t} U_{j, t} K_{j, t}^{P}\left(1-\tau_{t}^{K}\right) \\
-P_{t} K_{j, t}^{P}\left[\psi_{1}\left(U_{j, t}-1\right)+\frac{\psi_{2}}{2}\left(U_{j, t}-1\right)^{2}\right]+B_{j, t} \\
+S_{t} B_{j, t+1}^{F}-\frac{\chi_{B F}}{2}\left(B_{j, t+1}^{F}-B_{j, S S}^{F}\right) S_{t}+\omega_{R} T R A N S_{j, t} P_{t}
\end{aligned}
$$

and to the following law of motion for capital,

$$
K_{j, t+1}^{P}=(1-\delta) K_{j, t}^{P}+I_{j, t}^{P}\left[1-\frac{\chi}{2}\left(\frac{I_{j, t}^{P}}{S_{t}^{I} I_{j, t-1}^{P}}-1\right)^{2}\right]
$$

The intertemporal preference shock:

$$
\log S_{t}^{P}=\rho^{P} \log S_{t-1}^{P}+\varepsilon_{P, t}
$$

where $\varepsilon_{P, t} \sim N\left(0, \sigma^{P}\right)$.

The labor supply shock:

$$
\log S_{t}^{L}=\rho^{L} \log S_{t-1}^{L}+\varepsilon_{L, t}
$$

where $\varepsilon_{L, t} \sim N\left(0, \sigma^{L}\right)$. 
The quality of investment shock:

$$
\log S_{t}^{I}=\rho^{I} \log S_{t-1}^{I}+\varepsilon_{I, t}
$$

where $\varepsilon_{I, t} \sim N\left(0, \sigma^{I}\right)$.

where $E_{t}$ is the expectations operator, $0<\beta<1$ is the intertemporal discount factor, $C_{R}$ denotes consumption, $L_{R}$ denotes labor, $S^{P}$ refers to the intertemporal shock, $S^{L}$ is the shock on labor supply, $\varphi$ is the marginal disutility of labor and $\sigma$ is the coefficient of relative risk aversion.

Regarding the budget constraint, $P$ is the general price level, $I^{P}$ is private investment, $B$ is a one-year government bond, $B^{F}$ is a oneyear foreign bond, $R^{B}$ is the rate of return on the government bond (basic interest rate), $R^{F}$ denotes the world interest rate, $S$ is the nominal exchange rate, $W$ is the wage, $R$ is the return to capital, $K^{P}$ is the private stock of capital, $U$ is the capital utilization rate, $\chi$ is a parameter governing the adjustment cost's sensitivity, TRANS is the net income transfers to households by the government, $\tau^{C}, \tau^{L}, \tau^{K}$ stand for the consumption tax rate, labor-income tax rate and capital-income tax rate, respectively. The term $\left[\frac{\chi_{B F}}{2}\left(B_{j, t+1}^{F}-B_{j, S S}^{F}\right) S_{t}\right]$ stationarity-inducing technique (SCHMITT-GROHÉ and URIBE, 2003).

We adopt the convention that $B$ and $B^{F}$ are the nominal bonds issued in (t-1) and matured in t. For convenience, all bonds are regarded to be one-period bonds. Hence, both $B_{t+1}, B_{t+1}^{F}$ and $K_{t+1}^{P}$ are decided in $\mathrm{t}$.

Solving the Ricardian household's problem, we are left with the following first-order conditions:

$$
\begin{gathered}
\lambda_{R, j, t} P_{t}\left(1+\tau_{t}^{C}\right)=S_{t}^{P}\left(C_{R, j, t}-\phi_{C} C_{R, j, t-1}\right)^{-\sigma}-\phi_{C} \beta E_{t}\left[S_{t+1}^{P}\left(C_{R, j, t+1}-\phi_{C} C_{R, j, t}\right)^{-\sigma}\right](7) \\
Q_{t}=\beta E_{t}(1-\delta) Q_{t+1}+\lambda_{R, j, t+1} R_{t+1} U_{j, t+1}\left(1-\tau_{t+1}^{K}\right) \\
\quad-\lambda_{R, j, t+1} P_{t+1}\left[\psi_{1}\left(U_{j, t+1}-1\right)+\frac{\psi_{2}}{2}\left(U_{j, t+1}-1\right)^{2}\right]
\end{gathered}
$$




$$
\begin{gathered}
\frac{R_{t}}{P_{t}}=\left(\frac{1}{1-\tau_{t+1}^{K}}\right)\left[\psi_{1}+\psi_{2}\left(U_{j, t+1}-1\right)\right] \\
\lambda_{R, j, t} P_{t}\left(1+\tau_{t}^{C}\right)-Q_{t}\left[1-\frac{\chi}{2}\left(\frac{I_{j, t}^{P}}{S_{t}^{I} I_{j, t-1}^{P}}-1\right)^{2}-\chi\left(\frac{I_{j, t}^{P}}{S_{t}^{I} I_{j, t-1}^{P}}\right)\left(\frac{I_{j, t}^{P}}{S_{t}^{I} I_{j, t-1}^{P}}-1\right)\right] \\
=\chi \beta E_{t}\left[\left(\frac{Q_{t+1}}{S_{t+1}^{I}}\right)\left(\frac{I_{j, t+1}^{P}}{I_{j, t}^{P}}\right)^{2}\left(\frac{I_{j, t+1}^{P}}{S_{t}^{I} I_{j, t}^{P}}-1\right)\right] \\
\frac{\lambda_{R, j, t}}{R_{t}^{B}}=\beta E_{t} \lambda_{R, j, t+1} \\
R_{t}^{F} \beta E_{t}\left(\lambda_{R, j, t+1} S_{t+1}\right)=\left(\lambda_{R, j, t} S_{t}\right)\left[1-\chi_{B}\left(B_{j, t+1}^{F}-B_{j, S}^{F}\right)\right]
\end{gathered}
$$

\subsubsection{Determining consumption and saving of the non-Ricardian household}

The non-Ricardian household's behavior is simpler owing to her liquidity constraint which does not enable her to maximize her utility intertemporally. Thus, the non-Ricardian agent's consumption must match her current income each period. In reality, even without access to "credit", this kind of agent would be able to carry over current income into the future (by saving). In order to make the model more tractable, this agent will be also assumed to be unable to save. Therefore, the problem faced by this non-Ricardian consumer is:

$$
\max _{C_{N R, j, t}} E_{t} \sum_{t=0}^{\infty} \beta^{t} S_{t}^{P}\left[\frac{\left(C_{N R, j, t}-\phi_{C} C_{N R, j, t-1}\right)^{1-\sigma}}{1-\sigma}-S_{t}^{L} \frac{L_{N R, j, t}^{1+\varphi}}{1+\varphi}\right]
$$

subject to her budget constraint,

$$
P_{t}\left(1+\tau_{t}^{C}\right) C_{N R, j, t}=W_{t} L_{N R, j, t}\left(1-\tau_{t}^{L}\right)+\left(1-\omega_{R}\right) T R A N S_{t} P_{t}
$$


The first-order condition is the following:

$$
\lambda_{N R, j, t} P_{t}\left(1+\tau_{t}^{C}\right)=S_{t}^{P}\left(C_{N R, j, t}-\phi_{C} C_{N R, j, t-1}\right)^{-\sigma}-\phi_{C} \beta E_{t}\left[S_{t+1}^{P}\left(C_{N R, j, t+1}-\phi_{C} C_{N R, j, t}\right)^{-\sigma}\right]
$$

\subsubsection{Wage setting}

The household's choice over the wage level entails the assumption that this agent supplies differentiated labor under a monopolistically competitive framework. This service is sold to a representative labor aggregator which combines all those different labor services $\left(L_{J}\right)$ into a single input $(L)$ by means of the Dixit-Stiglitz technology.

$$
\max _{L_{j, t}} W_{t} L_{t}-\int_{0}^{1} W_{j, t} L_{j, t} d j
$$

subject to the following technology:

$$
L_{t}=\left(\int_{0}^{1} L_{j, t} \frac{\psi_{W}-1}{\psi_{W}} d j\right)^{\frac{\psi_{W}}{\psi_{W}-1}}
$$

The first-order condition is given by:

$$
L_{j, t}=L_{t}\left(\frac{W_{t}}{W_{j, t}}\right)^{\psi_{W}}
$$

This equation represents the household j's demand for labor. Plugging the latter into the preceding technology (17) results in the aggregate wage level:

$$
W_{t}=\left(\int_{0}^{1} W_{j, t}{ }^{1-\psi_{W}} d j\right)^{\frac{1}{1-\psi_{W}}}
$$

In each period, a share $1-\theta_{W}$ of households, which are randomly and independently chosen, set their wage in an optimal manner. The remaining households, $\theta_{W}$, follow a sticky-wage rule $\left(W_{j, t}=W_{j, t-1}\right)$. 
In taking the decision to pick their wage level in the period $\mathrm{t}$, the wage-setting households are aware they face the probability $\theta_{W}{ }^{N}$ of the wage being fixed for $\mathrm{N}$ periods in the future, regardless of whether the household makes the optimal choice $W_{j, t}{ }^{*}$ in the current period. Accordingly, the household seeks to solve the following problem:

$\max _{W_{j, t}} E_{t} \sum_{i=0}^{\infty}\left(\beta \theta_{W}\right)^{i}\left\{-S_{t+i}^{P} S_{t+i}^{L}\left(\frac{L_{Z, j, t+i}{ }^{1+\varphi}}{1+\varphi}\right)-\lambda_{Z, t+i}\left[W_{j, t}{ }^{*} L_{Z, j, t+i}\left(1-\tau_{t+i}^{L}\right)\right]\right\}$

where $Z=\{R, N R\}$.

subject to the household j's demand for labor (18).

Solving that problem yields the following first-order conditions for both the Ricardian and non-Ricardian households:

$$
\begin{aligned}
& W_{j, t}^{*}=\left(\frac{\psi_{W}}{\psi_{W}-1}\right) E_{t} \sum_{i=0}^{\infty}\left(\beta \theta_{W}\right)^{i}\left[\frac{S_{t+i}^{P} S_{t+i}^{L} L_{R, j, t+i}{ }^{\varphi}}{\lambda_{R, t+i}\left(1-\tau_{t+i}^{L}\right)}\right] \\
& W_{j, t}^{*}=\left(\frac{\psi_{W}}{\psi_{W}-1}\right) E_{t} \sum_{i=0}^{\infty}\left(\beta \theta_{W}\right)^{i}\left[\frac{S_{t+i}^{P} S_{t+i}^{L} L_{N R, j, t+i}}{\lambda_{N R, t+i}\left(1-\tau_{t+i}^{L}\right)}\right]
\end{aligned}
$$

Because a share $1-\theta_{W}$ of the households elect the same nominal wage, $W_{J, t}^{*}=W_{t}^{*}$, and the remaining share, $\theta_{W}$, receive the same wage as in the preceding period, the aggregate nominal wage can be written as follows:

$$
W_{t}=\left[\theta_{W} W_{t-1}^{1-\psi_{W}}+\left(1-\theta_{W}\right) W_{t}^{* 1-\psi_{W}}\right]^{\frac{1}{1-\psi_{W}}}
$$

The gross wage-inflation rate can be defined as:

$$
\pi_{W, t}=\frac{W_{t}}{W_{t-1}}
$$




\subsection{Combining consumption and labor}

Aggregate consumption and labor, respectively, are given by:

$$
\begin{aligned}
& C_{t}=\omega_{R} C_{R, t}+\left(1-\omega_{R}\right) C_{N R, t} \\
& L_{t}=\omega_{R} L_{R, t}+\left(1-\omega_{R}\right) L_{N R, t}
\end{aligned}
$$

\subsection{Firms}

\subsubsection{Final good producer (Retail)}

From an aggregate perspective, monopolistic competition involves, among other things, confronting the fact that consumers purchase a great variety of goods with the need of modeling in which the consumer is assumed to buy only a specific kind of good (a bundle comprised of all goods). This aggregate good is sold by a perfectly competitive retail firm. In other words, all the retailers are assumed identical to each other.

With the target of producing a bundle, the retailer must buy a large amount of wholesale goods. These are the inputs used in its production process. Thus, the retail firm acquires a great variety of wholesale goods (clothing, electronics, etc.) and bundles them into a final good (a basket of goods) which will be sold to the final consumer. In order to pose the problem faced by the retailer and solve for it, we must first describe its production technology. The aggregation technology is given by the Dixit-Stiglitz aggregator (DIXIT and STIGLITZ, 1977).

$$
Y_{t}=\left(\int_{0}^{1} Y_{j, t} \frac{\psi-1}{\psi} d j\right)^{\frac{\psi}{\psi-1}}
$$

where $Y_{t}$ is the retailers' output over periods t, and $Y_{j, t}$ for $j \in[0,1]$ is the wholesale good j. $\psi>1$ refers to the elasticity of substitution between wholesale goods. 
It should be noted that the price of each wholesale good is taken as given by the retailer. Knowing that $P_{t}$ and $P_{j, t}$ denote the nominal prices of the retail good and the wholesale good $\mathrm{j}$, respectively, the representative retail firm's maximization problem takes the form:

$$
\max _{Y_{j, t}} Y_{t} P_{t}-\int_{0}^{1} P_{j, t} Y_{j, t} d j
$$

Substituting the aggregator (27) into the last Equation (28) leads to the following expression:

$$
\max _{Y_{j, t}}\left(\int_{0}^{1} Y_{j, t} \frac{\psi-1}{\psi} d j\right)^{\frac{\psi}{\psi-1}} P_{t}-\int_{0}^{1} P_{j, t} Y_{j, t} d j
$$

By taking the first-order condition of the above problem, we get:

$$
Y_{j, t}=Y_{t}\left(\frac{P_{t}}{P_{j, t}}\right)^{\psi}
$$

This function portrays the demand for the wholesale good $\mathrm{j}$, which rises with aggregate demand and is inversely related to its relative price level.

Plugging Equation (30) into Equation (27) yields the aggregate price level:

$$
P_{t}=\left(\int_{0}^{1} P_{j, t}{ }^{1-\psi} d j\right)^{\frac{1}{1-\psi}}
$$

\subsubsection{Intermediate good producer (wholesale)}

Taking into account that domestic output is given by $Y=\left\{C, I^{P}, G, X\right\}$, an intermediate-good producing firm solves its problem in three steps: First, it chooses labor and capital so as to produce domestic inputs; right after, in order to determine the level 
of its output, it chooses between domestic inputs versus imported inputs; finally, it sets the price of the good it sells.

In the first step, the firm operates under perfect competition and produces a domestic input, $I N P_{j, t}^{D}$, using the following technology:

$$
I N P_{j, t}^{D}=A_{t} K_{j, t}^{P \alpha_{1}} L_{j, t}^{\alpha_{2}} K_{j, t}^{G}
$$

where $\alpha_{1}, \alpha_{2}$ and $\alpha_{3}$ stand for the share of private capital, labor and public capital in the production of domestic inputs, $A$ captures the economy's level of technology which obeys the following law of motion:

$$
\log A_{t}=\rho^{A} \log A_{t-1}+\varepsilon_{A, t}
$$

where $\varepsilon_{A, t} \sim N\left(0, \sigma^{A}\right)$.

Hence, the firm's goal is to minimize the cost of production:

$$
\min _{K_{j, t}^{P}, L_{j, t}} R_{t} K_{j, t}^{P}+W_{t} L_{j, t}
$$

subject to the prior technological restriction (31).

It is not difficult to show that the first-order conditions with respect to $K_{j, t}^{P}$ and $L_{j, t}$ are:

$$
\begin{gathered}
L_{j, t}=\alpha_{2} \frac{I N P_{j, t}^{D}}{W_{t} / P_{t}^{D}} \\
U_{t} K_{j, t}^{P}=\alpha_{1} \frac{I N P_{j, t}^{D}}{R_{t} / P_{t}^{D}}
\end{gathered}
$$


The marginal cost is given by:

$$
P_{t}^{D}=\left(\frac{1}{A_{t} K_{j, t}^{G} \alpha_{3}}\right)\left(\frac{R_{t}}{\alpha_{1}}\right)^{\alpha_{1}}\left(\frac{W_{t}}{\alpha_{2}}\right)^{\alpha_{2}}
$$

In the second step, as already mentioned, the firm engages in decision-making regarding the choice between using domestic inputs versus imported ones by means of the following technology:

$$
Y_{j, t}=\left[\omega_{D}^{\frac{1}{\psi_{D}}} I N P_{j, t}^{D} \frac{\psi_{D}-1}{\psi_{D}}+\left(1-\omega_{D}\right)^{\frac{1}{\psi_{D}}} I M P_{j, t}^{\frac{\psi_{D}-1}{\psi_{D}}}\right]^{\frac{\psi_{D}}{\psi_{D}-1}}
$$

where $\omega_{D}$ represents the share of the domestic input in the production of the intermediate good, and $\psi_{D}$ is the elasticity of substitution between domestic inputs and imported ones.

So the firm's problem at this stage can be formally stated as:

$$
\min _{I N P_{j, t}^{D} I M P_{j, t}} P_{t}^{D} I N P_{j, t}^{D}+I M P_{j, t} S_{t} P_{t}^{F}
$$

subject to the above technology.

By solving the previous problem, we obtain the following first-order condition:

$$
I N P_{j, t}^{D}=\omega_{D}\left(\frac{M C_{j, t}}{P_{t}^{D}}\right)^{\psi_{D}} Y_{j, t}
$$

and,

$$
I M P_{j, t}=\left(1-\omega_{D}\right)\left(\frac{M C_{j, t}}{S_{t} P_{t}^{F}}\right)^{\psi_{D}} Y_{j, t}
$$

And the marginal cost is:

$$
M C_{j, t}=\left[\omega_{D} P_{t}^{D^{1-\psi_{D}}}+\left(1-\omega_{D}\right) S_{t} P_{t}^{F^{1-\psi_{D}}}\right] \frac{1}{1-\psi_{D}}
$$




\subsubsection{Pricing a la Calvo}

The third step of this problem amounts to setting the price of its good. This wholesale firm decides how much to produce in every period according to the Calvo rule (CALVO, 1983). There is a probability $\theta$ that the firm keeps the price of the good fixed in the next period $\left(P_{j, t}=P_{j, t-1}\right)$ and a probability $(1-\theta)$ that it sets the price optimally $\left(P_{j, t}^{*}\right)$. Once the price has been set in period $t$, there is the probability $\theta$ that this price will remain fixed in period $\mathrm{t}+\mathrm{l}$, a probability $\theta^{2}$ that this price will remain fixed in period $t+2$, and so on. Accordingly, this firm should take into account these probabilities when setting the price of its own good. The problem of the firm that adjusts the price of the good in period $t$ is:

$$
\max _{P_{j, t}^{*}} E_{t} \sum_{i=0}^{\infty}(\beta \theta)^{i}\left(P_{j, t}^{*}-M C_{j, t+i}\right) Y_{j, t+i}
$$

subject to the demand for good $Y_{j, t+i}$ (30).

The following first-order condition is obtained by rearranging further the preceding equation:

$$
P_{j, t}^{*}=\left(\frac{\psi}{\psi-1}\right) E_{t} \sum_{i=0}^{\infty}(\beta \theta)^{i} M C_{j, t+i}
$$

It is worth noting that all wholesale firms setting their prices share the same markup over the same marginal cost. This means that in all periods $P_{j, t}^{*}$ the price is the same for all $(1-\theta)$ firms adjusting their prices. Combining now the pricing rule (31) with the assumption that all price-changing firms set an equal price and that price-maintaining firms leave the price unaffected - since they share the same technology -, yields the overall final price:

$$
P_{t}=\left[\theta P_{t-1}^{1-\psi}+(1-\theta) P_{t}^{* 1-\psi}\right]^{\frac{1}{1-\psi}}
$$




\subsection{Government}

In our model the government comes into the picture by splitting itself into two different entities: a fiscal authority and a monetary authority. The former is held responsible for conducting fiscal policy, while the latter pursues the price stability through a Taylor rule.

\subsubsection{Fiscal authority}

The fiscal authority is tasked with taxing households' income and issuing debt to finance its outlays, namely: current expenditure, $G_{t}$ ; public investment, $I_{t}^{P}$; and net transfers to households, TRANS $S_{t}$. So the government's budget constraint can be represented by:

$$
\frac{B_{j, t+1}}{R_{t}^{B}}-B_{j, t}+T_{t}=P_{t} G_{t}+P_{t} I_{t}^{G}+P_{t} \operatorname{TRANS}_{t}
$$

The overall tax collection would be:

$$
T_{t}=P_{t} \tau_{t}^{C}\left(C_{R, j, t}+I_{j, t}^{P}\right) W_{t} L_{R, j, t} \tau_{t}^{L}+\left(R_{t}-\delta\right) K_{j, t}^{P} \tau_{t}^{K}
$$

The fiscal authority has three expenditure-based fiscal policy tools at its disposal: $G_{t} ; I_{t}^{P}$; and $T R A N S_{t}$. On the revenue side, the tools the fiscal authority falls back on are: $\tau_{t}^{C} ; \tau_{t}^{L}$; and $\tau_{t}^{K}$. All these instruments follow the same fiscal policy rule:

$$
\frac{Z_{t}}{Z_{S}}=\left(\frac{Z_{t-1}}{Z_{S}}\right)^{\gamma_{Z}}\left(\frac{B_{t}}{Y_{t-1} P_{t-1}} \frac{Y_{S} P_{S}}{B_{S}}\right)^{\left(1-\gamma_{Z}\right) \phi_{Z}} S_{t}^{Z}
$$

where $\gamma_{Z}$ and $\phi_{Z}$ are parameters capturing the importance of these fiscal policy tools relative to public debt sustainability, and the importance of the rule debt level relative to GDP, respectively, and $Z=\left\{G_{t}, I_{t}^{G}, T R A N S_{t}, \tau_{t}^{C}, \tau_{t}^{L}, \tau_{t}^{K}\right\}$.

The fiscal shock can be expressed as:

$$
\log S_{t}^{Z}=\rho^{Z} \log S_{t-1}^{Z}+\varepsilon_{Z, t}
$$

where $\varepsilon_{Z, t} \sim N\left(0, \sigma^{Z}\right)$. 
Likewise, the stock of public capital evolves according to the wellknown law of motion:

$$
K_{t+1}^{G}=\left(1-\delta_{G}\right) K_{t}^{G}+I_{t}^{G}
$$

where $\delta_{G}$ denotes the rate of depreciation of public capital.

\subsubsection{Monetary authority}

The Central Bank's task is twofold: to foster output growth and to attain price stability. In order to accomplish this dual goal, it pursues a simple Taylor rule:

$$
\frac{R_{t}^{B}}{R_{S}^{B}}=\left(\frac{R_{t-1}^{B}}{R_{S}^{B}}\right)^{\gamma_{R}}\left[\left(\frac{\pi_{t}}{\pi_{S}}\right)^{\gamma_{\pi}}\left(\frac{Y_{t}}{Y_{S}}\right)^{\gamma_{Y}}\right]^{\left(1-\gamma_{R}\right)} S_{t}^{m}
$$

where $\gamma_{Y}$ and $\gamma_{\pi}$ are the sensibilities of the interest rate to output and to the inflation rate, respectively, and $\gamma_{R}$ is a stabilization parameter. $S_{t}^{m}$ is the monetary shock, which abides by the following expression:

$$
\log S_{t}^{m}=\rho^{m} \log S_{t-1}^{m}+\varepsilon_{m, t}
$$

where $\varepsilon_{m, t} \sim N\left(0, \sigma^{m}\right)$.

\subsection{External sector}

The external sector is represented by the demand for the exported good, by the equilibrium condition of the balance of payments, and by the law of motion governing the movement of the foreign interest rate and the import price level. The export demand obeys a rule which depends on a stabilization component, on the real exchange rate and on a stochastic component:

$$
\frac{X_{t}}{X_{S}}=\left(\frac{X_{t-1}}{X_{S}}\right)^{\gamma_{X}}\left[\frac{S_{t-1} / P_{t-1}}{S_{S} / P_{S}}\right]^{\left(1-\gamma_{X}\right) \phi_{X}} S_{t}^{X}
$$


where $\gamma_{X}$ is a stabilization parameter, $\phi_{X}$ is the sensibility of exports to the real exchange rate and $S_{t}^{X}$ is the shock to export demand, which is given by:

$$
\log S_{t}^{X}=\rho^{X} \log S_{t-1}^{X}+\varepsilon_{X, t}
$$

where $\varepsilon_{X, t} \sim N\left(0, \sigma^{X}\right)$.

The external-sector balanced condition (balance of payments) can be stated as:

$$
S_{t}\left(B_{t+1}^{F}-B_{t}^{F} R_{t-1}^{F}\right)=P_{t}^{F} S_{t} I M P_{t}-P_{t} X_{t}
$$

The laws of motion for foreign interest rates and import price level are defined as:

$$
\log R_{t}^{F}=\rho^{R} \log R_{t-1}^{F}+\varepsilon_{R, t}
$$

where $\varepsilon_{R F, t} \sim N\left(0, \sigma^{R F}\right)$.

$$
\log R_{t}^{F}=\rho^{R F} \log R_{t-1}^{F}+\varepsilon_{R F, t}
$$

where $\varepsilon_{P F, t} \sim N\left(0, \sigma^{P F}\right)$.

\subsection{Equilibrium condition of the model}

Finally, to close the model, the good-market equilibrium condition is given by: $Y_{t}=C_{t}+I_{t}^{P}+I_{t}^{G}+G_{t}+X_{t}$

\section{Data}

We then proceed to estimate the model using quarterly data spanning from 2002Q1 to 2014Q4 (52 data points). We use 14 model variables as observables $\left(P, T R A N S, R T L, R T K p, R T C,{ }^{3}\right.$

${ }^{3} R T L=\tau^{L} W L, R T K p=\tau^{K} R K p$ and $R T C=\tau^{C}(C+I p)$ where RTL, RTKp and RTC are revenue collected from the taxes on labor income, on capital gains and on consumption. 
$\left.R^{B}, Y, C, G, C, X, I M P, R^{F}, S, L\right)$ which they are described in the Table 1. So, to prepare the data for the model estimation, we deflated using the IPCA, detrented and seasonally adjusted non stationary series using the software X12-ARIMA and applied first logdifference. We have chosen this set of observables due to data availability and their relevance to our research purposes. Furthermore, a large set of observables mitigates the problem of identification.

\section{Calibrated parameters, prior and posterior}

In this section we pursue a two-tier approach: the parameters not directly related to the questions which we endeavor to answer throughout this article are calibrated, while those relevant parameters for the analysis of the shock propagation are estimated using the Bayesian methodology. The main calibration procedure employed here is to pick up the values of parameters from other relevant articles in the DSGE model literature. Table 2 summarizes the calibration of the parameters.

Table 1 - Observables variables of the model

\begin{tabular}{|c|c|c|}
\hline Variable & Series & Source \\
\hline $\mathrm{P}$ & Series constructed using the IPCA (1\%a.m.) & IBGE/SNIPC \\
\hline TRANS & Benefícios assistenciais (LOAS e RMV) Rl\$ (milhões)\} & Min. Fazenda/STN \\
\hline RTL & IR - pessoas físicas R|\$ (milhões) & Min. Fazenda/SRF \\
\hline RTKp & IR - pessoas jurídicas R $\$$ (milhões) & Min. Fazenda/SRF \\
\hline RTC & ICMS and IPI RI\$ (milhões) & Min. Fazenda/SRF \\
\hline$R^{B}$ & Selic Over ( $1 \%$ a.m.) & BCB Boletim/M. Finan. \\
\hline Y & PIB - preço de mercado - RI\$ (milhões) & IBGE/SCN 2000 Trim. \\
\hline $\mathrm{G}$ & Consumo final - adm. pública - Rl\$ (milhões) & IBGE/SCN 2000 Trim. \\
\hline C & Consumo final - famílias - R|\$ (milhões) & IBGE/SCN 2000 Trim. \\
\hline $\mathrm{X}$ & Exportações - Rl\$ (milhões) & IBGE/SCN 2000 Trim. \\
\hline IMP & Importações - RI\$ (milhões) & IBGE/SCN 2000 Trim. \\
\hline $\mathrm{L}$ & Horas pagas - indústria geral - índice (jan. $2001=100$ ) & PIMES/IBGE \\
\hline$R^{F}$ & Estados Unidos - taxa de juros ( $1 \%$ a.a.) & $\begin{array}{l}\text { Fundo Monetário Internacional, } \\
\text { International Financial Statistics }\end{array}$ \\
\hline S & Taxa de câmbio - RI\$ / USI\$ - comercial - compra - média & $\begin{array}{l}\text { Banco Central do Brasil, Boletim, } \\
\text { Seção Balanço de Pagamentos } \\
\text { (BCB Boletim/BP) }\end{array}$ \\
\hline
\end{tabular}

Source: Own calculations.

Estud. Econ., São Paulo, vol.47, n.1, p.93-124 , jan.-mar. 2017 
Table 2 - Calibration of the Parameters

\begin{tabular}{|c|c|c|}
\hline Parameters & Value & Source \\
\hline$\beta$ & 0.985 & Cavalcanti and Vereda (2010) \\
\hline$\sigma$ & 2 & Cavalcanti and Vereda (2010) \\
\hline$\sigma$ & 1.5 & Cavalcanti and Vereda (2010) \\
\hline$\alpha_{1}$ & 0.3 & Mussolini (2011) \\
\hline$\alpha_{2}$ & 0.6 & Mussolini (2011) \\
\hline$\alpha_{3}$ & 0.1 & Mussolini (2011) \\
\hline$\delta$ & 0,025 & Cavalcanti and Vereda (2010) \\
\hline$\delta_{G}$ & 0.025 & Cavalcanti and Vereda (2010) \\
\hline$\omega_{R}$ & 0.6 & Castro et al (2011) \\
\hline$\frac{B_{S S}^{F}}{Y_{S S}}$ & $-0,1$ & Sensitivity Analysis (Iskrev, 2010) \\
\hline$\frac{B_{S S}}{Y_{S S}}$ & 1 & Sensitivity Analysis (Iskrev, 2010) \\
\hline$\frac{T R A N S_{S S}}{Y_{S S}}$ & 0,1 & Sensitivity Analysis (Iskrev, 2010) \\
\hline$\psi_{2}$ & 1 & Sensitivity Analysis (Iskrev, 2010) \\
\hline$\chi$ & 1 & Sensitivity Analysis (Iskrev, 2010) \\
\hline$\gamma_{G}$ & 0 & Stähler and Thomas (2012) \\
\hline$\phi_{G}$ & 0 & Stähler and Thomas (2012) \\
\hline$\gamma_{I G}$ & 0 & Stähler and Thomas (2012) \\
\hline$\phi_{I G}$ & 0 & Stähler and Thomas (2012) \\
\hline$\psi$ & $\left(1+\tau_{s}^{C}\right)\left[\frac{1}{\beta}-(1-\delta)\right]$ & Predetermined \\
\hline
\end{tabular}

Source: Own calculations.

Iskrev (2010) provides a method for testing the set of combination of parameters' values in order that Blanchard and Kahn (1980) conditions are met. Subsequently, from this set of values the procedure was to choose those values for the parameters that fulfill the conditions which are considered standard in the literature. As in 2014 the public sector net external debt was around $-10 \%$ of GDP, the parameter $\frac{B_{S S}^{F}}{Y_{S S}}$ was given a value of -0.1. Castro et al. (2011) give 
the ratio public debt to GDP a value of $200 \%$. In our view, the latter value is perhaps too high, so we opt to be more conservative and use $\frac{B_{S S}}{Y_{S S}}$ (ratio public debt to GDP a value of $100 \%$ ).

Obtaining the average value of total transfers from the government to households is by no means an easy task. This is why we reckon that a value of $10 \%$ as a percentage of GDP would be more than acceptable $\left(\frac{T R A N S_{S S} .}{Y_{S S}}=0.1\right)$. As regards the parameters $\psi_{2}$ and $\chi$, since they are not fiscal-policy-related variables, we decided to normalize these parameters to 1 .

The parameters $\gamma_{G}, \phi_{G}, \phi_{I G}$ and $\gamma_{I G}$ were set at zero, following Stahler and Thomas (2012). This choice implies that fiscal policy reacts through changes in taxes, and not through changes in government spending. This seems to be the case in key episodes of recent Brazilian economic history. For instance, at the outset of the Real plan, the fiscal consolidation process mainly rested on the CPMF (Temporary Tax on Financial Transactions, Contribuição Provisória sobre Movimentação Financeira in Portuguese). ${ }^{4}$ Given the prior distributions of the parameters, we estimate the posterior distributions using a Markov chain process via the Metropolis-Hastings algorithm with 100.000 iterations, a scale value 0.3 to be used for the jumping distribution, and 10 parallel chains for Metropolis-Hastings algorithm. ${ }^{5}$ The results of the Bayesian estimation are shown in Table 3 and Figure 1.

These graphs are especially relevant in that they present key results, but they can also serve as tools to detect problems or build additional confidence in one's results. First, the prior and the posterior distribution should not be excessively different from one another. Second, the posterior distributions should be close to normal, or at least not display a shape that is clearly non-normal. Third, the green mode should not be too far away from the mode of the posterior distribution. Overall, it is worth pointing out that the estimates proved to be quite satisfactory.

4 See Giambiagi $(2008,2009)$.

5 For information on the Bayesian estimation, consult: De Jong and Dave, 2007; and Canova, 2007. 
Table 3 - Posterior distribution of the model

\begin{tabular}{|c|c|c|c|c|c|}
\hline Parameter & prior mean & post. mean & 901\% HPD interval & prior & pstdev \\
\hline$\tau_{S S}^{C}$ & 0.160 & 0.1640 & 0.15190 .1760 & beta & 0.0100 \\
\hline$\tau_{S S}^{L}$ & 0.170 & 0.1772 & 0.16940 .1855 & beta & 0.0100 \\
\hline$\tau_{S S}^{K}$ & 0.080 & 0.0616 & 0.05280 .0702 & beta & 0.0100 \\
\hline$\gamma_{T R A N S}$ & 0.500 & 0.5614 & 0.45600 .6900 & beta & 0.1000 \\
\hline$\gamma_{\tau C}$ & 0.500 & 0.7303 & 0.64090 .8369 & beta & 0.1000 \\
\hline$\gamma_{\tau L}$ & 0.500 & 0.5166 & 0.42440 .6037 & beta & 0.1000 \\
\hline$\gamma_{\tau K}$ & 0.500 & 0.4959 & 0.37640 .6131 & beta & 0.1000 \\
\hline$\phi_{T R A N S}$ & -0.500 & -0.2750 & $-0.5127-0.0897$ & unif & 0.2887 \\
\hline$\phi_{\tau C}$ & 0.500 & 0.5632 & 0.28021 .0000 & unif & 0.2887 \\
\hline$\phi_{\tau L}$ & 0.500 & 0.0163 & 0.00000 .0404 & unif & 0.2887 \\
\hline$\phi_{\tau K}$ & 0.500 & 0.0374 & 0.00000 .0794 & unif & 0.2887 \\
\hline$\chi_{B F}$ & -0.003 & -0.0045 & $-0.0050-0.0039$ & unif & 0.0014 \\
\hline$\gamma_{X}$ & 0.500 & 0.5042 & 0.39530 .6010 & beta & 0.1000 \\
\hline$\phi_{X}$ & 0.500 & 0.1456 & 0.00000 .3211 & unif & 0.2887 \\
\hline$\omega_{D}$ & 0.850 & 0.8364 & 0.82400 .8493 & beta & 0.0100 \\
\hline$\psi_{D}$ & 5.000 & 3.2352 & 2.80443 .6456 & gamma & 0.5000 \\
\hline$\phi_{I N S D}$ & 0.850 & 0.8787 & 0.82800 .9330 & beta & 0.0500 \\
\hline$\theta$ & 0.750 & 0.7445 & 0.72850 .7587 & beta & 0.0100 \\
\hline$\theta_{W}$ & 0.750 & 0.7535 & 0.74430 .7638 & beta & 0.0100 \\
\hline$\psi$ & 10.000 & 13.0704 & 8.726918 .4005 & gamma & 5.0000 \\
\hline$\psi_{W}$ & 10.000 & 15.4805 & 9.200427 .2836 & gamma & 5.0000 \\
\hline$\phi_{C}$ & 0.800 & 0.7957 & 0.78500 .8052 & beta & 0.0100 \\
\hline$\gamma_{R}$ & 0.500 & 0.3262 & 0.23380 .4251 & beta & 0.1000 \\
\hline$\gamma_{Y}$ & 0.500 & 0.4530 & 0.39850 .5070 & gamma & 0.0500 \\
\hline$\gamma_{\pi}$ & 3.000 & 3.0646 & 2.95393 .1823 & gamma & 0.1000 \\
\hline$\rho_{a}$ & 0.500 & 0.5549 & 0.48370 .6312 & beta & 0.1000 \\
\hline$\rho_{G}$ & 0.500 & 0.4751 & 0.36750 .5866 & beta & 0.1000 \\
\hline$\rho_{K G}$ & 0.500 & 0.5187 & 0.42880 .6076 & beta & 0.1000 \\
\hline$\rho_{\text {TRANS }}$ & 0.500 & 0.5713 & 0.47290 .6780 & beta & 0.1000 \\
\hline$\rho_{\tau C}$ & 0.500 & 0.5450 & 0.42740 .6552 & beta & 0.1000 \\
\hline$\rho_{\tau L}$ & 0.500 & 0.3698 & 0.26770 .4684 & beta & 0.1000 \\
\hline$\rho_{\tau K}$ & 0.500 & 0.6862 & 0.54640 .8346 & beta & 0.1000 \\
\hline
\end{tabular}


Table 3 - Posterior distribution of the model - (continuation)

\begin{tabular}{|l|l|l|l|l|l|}
\hline Parameter & prior mean & post. mean & $901 \%$ HPD interval & prior & pstdev \\
\hline$\rho_{m}$ & 0.500 & 0.5450 & 0.38920 .7256 & beta & 0.1000 \\
\hline$\rho_{P}$ & 0.500 & 0.4334 & 0.36650 .5150 & beta & 0.1000 \\
\hline$\rho_{L}$ & 0.500 & 0.4571 & 0.35230 .5652 & beta & 0.1000 \\
\hline$\rho_{I}$ & 0.500 & 0.6123 & 0.52760 .7025 & beta & 0.1000 \\
\hline$\rho_{X}$ & 0.500 & 0.4939 & 0.38380 .6053 & beta & 0.1000 \\
\hline$\rho_{R F}$ & 0.500 & 0.5828 & 0.49280 .6684 & beta & 0.1000 \\
\hline$\rho_{P F}$ & 0.500 & 0.7764 & 0.69530 .9045 & beta & 0.1000 \\
\hline$\varepsilon$ & 1.0 & 0.1321 & 0.11760 .1476 & invg & Inf \\
\hline$\varepsilon_{G}$ & 1.0 & 0.1308 & 0.11760 .1452 & invg & Inf \\
\hline$\varepsilon_{I G}$ & 1.0 & 1.3021 & 0.98081 .7152 & invg & Inf \\
\hline$\varepsilon_{T R A N S}$ & 1.0 & 0.5577 & 0.29820 .7773 & invg & Inf \\
\hline$\varepsilon_{\tau C}$ & 1.0 & 0.2236 & 0.16200 .2732 & invg & Inf \\
\hline$\varepsilon_{\tau L}$ & 1.0 & 0.1827 & 0.15040 .2129 & invg & Inf \\
\hline$\varepsilon_{\tau K}$ & 1.0 & 0.2195 & 0.17980 .2587 & invg & Inf \\
\hline$\varepsilon_{m}$ & 1.0 & 0.1272 & 0.11760 .1383 & invg & Inf \\
\hline$\varepsilon_{P}$ & 1.0 & 0.3266 & 0.19550 .4582 & invg & Inf \\
\hline$\varepsilon_{L}$ & 1.0 & 0.4286 & 0.22290 .6244 & invg & Inf \\
\hline$\varepsilon_{I}$ & 1.0 & 0.5671 & 0.40550 .7249 & invg & Inf \\
\hline$\varepsilon_{X}$ & 1.0 & 0.1386 & 0.11760 .1561 & invg & Inf \\
\hline$\varepsilon_{R F}$ & 1.0 & 0.1267 & 0.11760 .1377 & invg & Inf \\
\hline$\varepsilon_{P F}$ & 1.0 & 0.1468 & 0.12140 .1691 & invg & Inf \\
\hline & & & & & \\
\hline
\end{tabular}

Source: Own elaboration. 

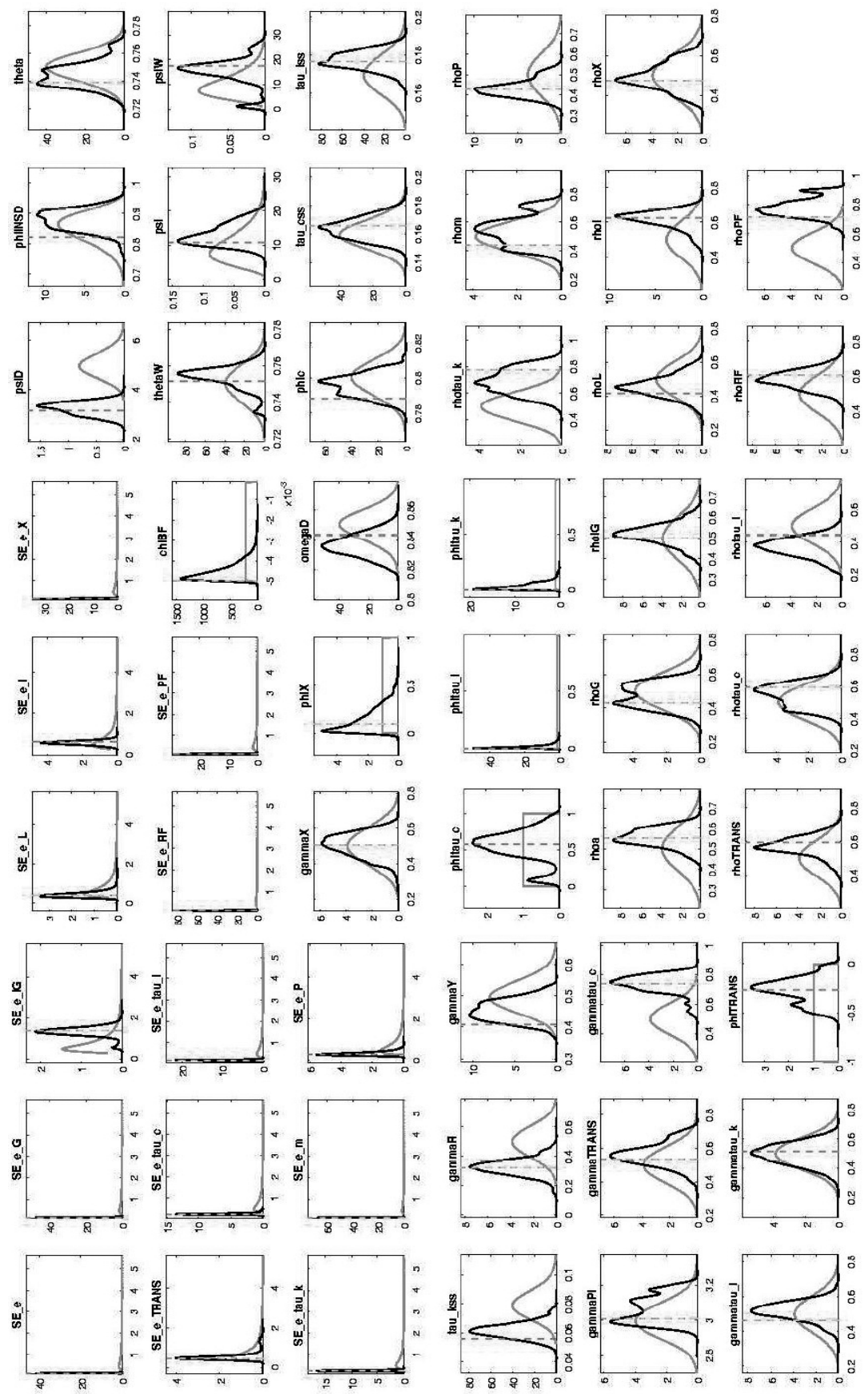

Figure 1- Priors and posteriors.

SourceOwn calculations. 


\section{Results}

This section analyzes the dynamic properties of the model by focusing on the shocks decomposition of the GDP and the fiscal multipliers.

\subsection{Shocks decomposition}

One way to assess the effects of the different shocks on GDP fluctuations is to look into the decomposition of these shocks (Figure 2). Two variables were found relevant in accounting for the output behavior: current spending and public investment. Both performed similarly, reducing output over the period 2003 to 2006, as a strong fiscal adjustment was under way. However, during the period in which the Growth Acceleration Programs (PAC, in Portuguese) prevailed - PACl and PAC2 were initiated in 2007 and 2010, respectively -, government expenditure and public investment played an important role in boosting aggregate demand.

\subsection{Fiscal multipliers analysis}

In this section, we turn to gauging the fiscal multipliers for each fiscal shock (Figure 3). The results are in accordance with what was presented in Section 2, namely, in the small-economy case the multipliers should be smaller than 0.5 - it is worth remarking that these would be even smaller if there were a pressing need to put the fiscal house in order to keep public debt stable (Spilimbergo et al., 2009). The greatest multiplier found in this work was that of the consumption-tax excise reduction. Its associated value was 0.09 on impact, reaching 0.12 at 8 periods, with this number falling steadily over 16 quarters on the grounds of the need to adjust other fiscal tools, since the falling tax revenues led to a growing public debt (perceived effect by MOURA (2015) and by CAVALCANTI and SILVA (2010)). This growth was, however, temporary and the multiplier resumed growing.

The second-largest multiplier is the one associated with public spending. On impact, its value was 0.055 . The ensuing fiscal adjustment caused this value to drop (for the same reason as in the case of the 
preceding multiplier), bottoming out at 0.04 and then bouncing back thereafter until reaching a stable level. Concerning the public-investment multiplier, its value on impact was smaller than the earlier figures, 0.003, it thereon embarked on a downward path (thereby mimicking somehow the behavior of the prior fiscal measures' multipliers) but its upward trajectory after the rebounding was steeper than those of the previous fiscal policies. The reason is that a positive shock to public investment renders firms more productive as the higher investment turns into capital stock (In the same way as in MOURA (2015)).

The only income-tax measure yielding a positive multiplier is the tax exemption from labor income. On impact, the value was modest - 0.005 -, but in the longer run this number improved due to the increase in the households' labor supply. The same policy applied to capital income gave rise to a negative result at any horizon.

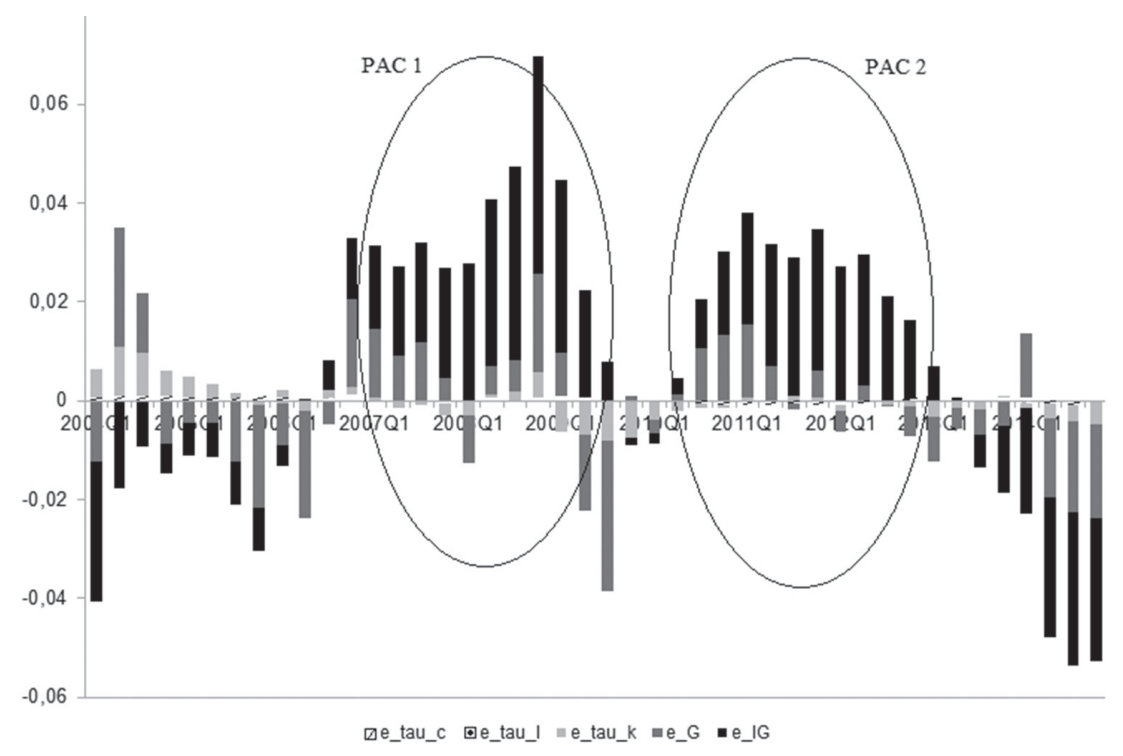

Figure 2 - GDP Shocks Decomposition

Source: Own calculations. 


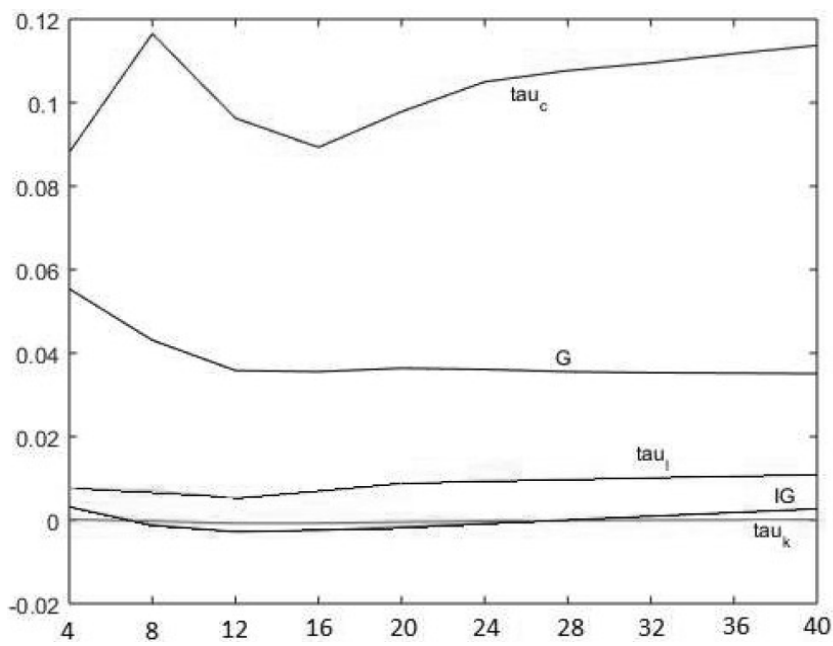

Figure 3 - Fiscal multipliers for each fiscal shock

Source: Own calculations.

\section{Conclusions}

This article intended to make a contribution to the discussion about the effects of the Brazilian fiscal policy after the 2008 crisis. In this vein, a shocks decomposition for Brazilian GDP as well as a multiplier analysis of each fiscal shock were undertaken under the framework of a New Keynesian model. The spending-based measures were the most successful in affecting GDP over the whole period studied, primarily because of PAC2, whose actual goal was to bolster aggregate demand. However, this stimulus program had a positive result until 2013, thereafter the deterioration of this type of fiscal policy negatively affected the Brazilian economic result.

The form chosen to compare the different possibilities of fiscal policies was the fiscal multiplier. The exemption of tax on consumption showed better results, followed by the multiplier of public spending. The other multipliers showed relatively insignificant. Given these results, relieve the tax on consumption and increase current spending would be the best possibilities to stimulate the economy. Still, it can be noted in the shocks decomposition, that this second policy was one of the tools used to stimulate the economy in the PAC programs. 


\section{Bibliography}

BATINI, N., EYRAUD, Luc and WEBER, A. A Simple Method to Compute Fiscal Multipliers. IMF Working Paper No. 14/93; June, 2014.

BLANCHARD, O. J. and KAHN, C. M. The Solution of Linear Difference Models under Rational Expectations. Econometrica, Econometric Society, vol. 48(5), pages 1305-11, July, 1980.

CALVO, G. Staggered Prices in A Utility-Maximizing Framework. Journal of Monetary Economics, 12, p. 383-398, 1983.

CANOVA, F. Methods for Applied Macroeconomic Research. New Jersey: Princeton University Press. 492 p, 2007.

CARVALHO, F. A., and VALLI, M. An estimated DSGE Model with Government Investment an Primary Surplus rule: the Brazilian case. $\$ 32^{\wedge} 0 \$$. Encontro da SBE, Salvador: SBE, 2010. Available in:

http://bibliotecadigital.fgv.br/ocs/idex.php/sbe/EBE10/paper/view/2141/1061. Accessed on: February $14,2016$.

CASTRO, M. R., GOUVEA, S. N., MINElla, A., SANTOS, R. and SOUZA-SOUBRINHO, N. F. SAMBA: Stochastic analytical model with a bayesian approach. Banco Central do Brail. Working Papers Series n. 29, p. 1-138, 2011. In: hhttp://bcb.gov.br/pec/wps/ingl/wps239.pdf. Acesso em: 02 out 2013.

CAVAlCANTI, M. A. F. H., and VEREDA, L. Propriedades dinamicas de um modelo DSGE com parametrizacoes alternativas para o Brasil. Ipea, Texto para Discussão, n 1588, 2010.

CAVALCANTI, M. A. F. H. and SILVA, N. L. C. Dívida pública, política fiscal e nível de atividade: uma abordagem VAR para o Brasil no período 1995-2008. Economia Aplicada, 14(4), 391-418, 2010.

CAVALCANTI, M. A. F. H., and VEREDA, L. (in press). Fiscal Policy Multipliers in a DSGE Model for Brazil, 2016. Available in: http://bibliotecadigital.fgv.br/ojs/index.php/bre/article/view/57570.

Accessed on: February 14, 2016.

CHRISTIANO, L., EICHENBAUM, M. and REBELO, S. When is the government spending multiplier large? NBER working paper series, working paper 15394, 2009.

DEJONG, D., N., and DAVE, C. Structural Macroeconometrics. New Jersey: Princeton University Press. 338 p., 2007.

DIXIT, A. K. and STIGLITZ, J. E. Monopolistic competition and optimum product diversity. The American Economic Review, 67, p. 297-308, 1977.

FANTINATTI, A. M. Estímulos fiscais em um modelo DSGE: bens duráveis versus bens não duráveis. Dissertação de Mestrado Profissional. Fundação Getúlio Vargas - Escola de Economia São Paulo, 2015.

GIAMBIAGI, F. 18 anos de política fiscal no Brasil: 1991/2008. Economia aplicada, 12(4), 535-580, 2008.

A política fiscal do governo Lula em perspectiva histórica: qual é o limite para o aumento do gasto público? Planejamento e políticas públicas, (27), 2009.

ILZETZKI, E., MENDOZA, E.G. and VÉGH, C.A. How big (small?) are fiscal multipliers? Journal of Monetary Economics, 60, p. 239-254, 2013.

ISKREV, N. Local identification in DSGE models, Journal of Monetary Economics, 57(2), 189-202, 2010.

MENDONÇA, M. J. C., MEDRANO, L. A. and SACHISIDA, A. Avaliando a Condição da Política Fiscal no Brasil. Revista de Economia e Administração (Impresso), v. 9, p. 294-316, 2010.

MOREIRA, T. B. S. A crise financeira internacional e as políticas anticíclicas no Brasil. 2010. Disponível em: <www.tesouro.gov.br>.

MOURA, G. V. Multiplicadores Fiscais e Investimento em Infraestrutura. Rio de Janeiro: Revista Brasileira de Economia, v. 69, n.1, p. 75-104, 2015.

Estud. Econ., São Paulo, vol.47, n.1, p.93-124 , jan.-mar. 2017 
MUSSOLINI, C. C. Ensaios em politica fiscal. Tese de Doutorado (Doutorado em Economia de Empresas) Fundação Getúlio Vargas - Escola de Economia São Paulo, 2011.

PERES, M. A. F. and ELLERY JR., R. G. Efeitos dinâmicos dos choques fiscais do governo central do PIB do Brasil. Pesquisa e Planejamento Econômico, 39(2), 159-206, 2009.

SCHMITT-GROHÉ, S., and URIBE, Martín. Closing small open economy models. Journal of International Economics, 61, pg 163-185, 2003.

SPILIMBERGO, A., SYMANSKY, S. and SCHINDLER, M. Fiscal Multipliers. IMF Staff position note 2009/11 (Washington: International Monetary Fund), 2009.

STÄHLER, N., and THOMAS, C. FiMod-A DSGE model for fiscal policy simulations. Economic Modelling, 29(2), 239-261, 2012.

ZUBAIRY, S. On fiscal multipliers: estimates from a medium scale DSGE model. International Economic Review, v. 55, issue 1, p. 169-195, 2014.

WOODFORD, M. Simple analytics of the government expenditure multiplier. American Economic Journal: Macroeconomics, American Economic Association, vol. 3(1), pages 1-35, January, 2010. 